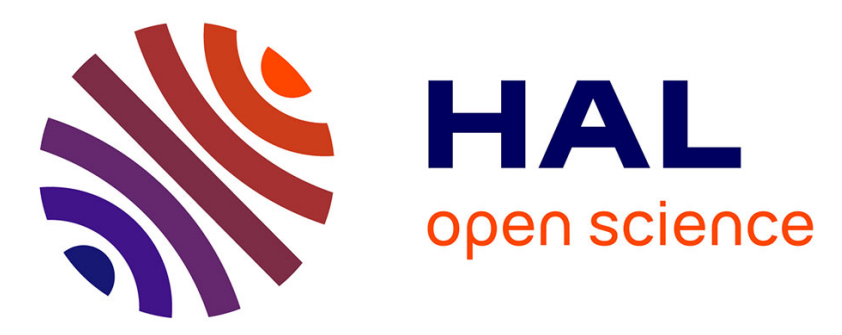

\title{
Transparent tantalum cluster-based UV and IR blocking electrochromic devices
}

\author{
A. Renaud, M. Wilmet, T.G. Truong, M. Seze, P. Lemoine, N. Dumait, W. \\ Chen, N. Saito, T. Ohsawa, T. Uchikoshi, et al.
}

\section{- To cite this version:}

A. Renaud, M. Wilmet, T.G. Truong, M. Seze, P. Lemoine, et al.. Transparent tantalum clusterbased UV and IR blocking electrochromic devices. Journal of Materials Chemistry C, 2017, 5 (32), pp.8160-8168. 10.1039/c7tc01964e . hal-01581225

HAL Id: hal-01581225

https://hal-univ-rennes1.archives-ouvertes.fr/hal-01581225

Submitted on 10 Sep 2020

HAL is a multi-disciplinary open access archive for the deposit and dissemination of scientific research documents, whether they are published or not. The documents may come from teaching and research institutions in France or abroad, or from public or private research centers.
L'archive ouverte pluridisciplinaire HAL, est destinée au dépôt et à la diffusion de documents scientifiques de niveau recherche, publiés ou non, émanant des établissements d'enseignement et de recherche français ou étrangers, des laboratoires publics ou privés. 


\section{J. Mater. Chem.C}

\section{ARTICLE}

\section{Transparent Tantalum Clusters-based UV and IR Blocking Electro- chromic Devices}

Received 00th January 20xx, Accepted 00th January 20xx

DOI: $10.1039 / \times 0 \times x 00000 x$

\author{
A. Renaud, ${ }^{a \mathrm{a}} \mathrm{M}$. Wilmet, ${ }^{\mathrm{ab}} \mathrm{T}$. G. Truong, ${ }^{\mathrm{a} M}$ M. Seze, ${ }^{\mathrm{a}} \mathrm{P}$. Lemoine, ${ }^{\mathrm{a}} \mathrm{N}$. Dumait, ${ }^{\mathrm{a} W}$ W. Chen, ${ }^{\mathrm{bc}} \mathrm{N}$. Saito, ${ }^{\text {be }} \mathrm{T}$. \\ Ohsawa, ${ }^{\text {de }}$ T. Uchikoshi, ${ }^{\text {bc }}$ N. Ohashi, ${ }^{\text {bde }}$ S. Cordier*a and F. Grasset ${ }^{* \text { bd }}$
}

www.rsc.org/

\begin{abstract}
The first integration by solution deposition process of tantalum octahedral clusters in multifunctional nanocomposite materials and devices for smart window is investigated in this study. Two $\left[\mathrm{Ta}_{6} \mathrm{Br}_{12}^{\mathrm{i}}\right]^{\mathrm{nt}}$ cluster cores-based high transparent visible UV and NIR filters are realized. Films are fabricated by incorporation of clusters in a polymer matrix and coating on ITO substrate. Electrochromic cell consists in the insertion of $\mathrm{Ta}_{6}$-based electrolyte between two transparent conductive electrodes. In both cases, the modification of the absorption properties in the visible and NIR spectral range is able by altering and controlling the oxidation state of the tantalum cluster. The stabilization of reduced $\left[\mathrm{Ta}_{6} \mathrm{Br}_{12}^{\mathrm{i}}\right]^{2+}$ or oxidized $\left[\mathrm{Ta}_{6} \mathrm{Br}_{12}^{\mathrm{i}}\right]^{3+/ 4+}$ species leads to green-emerald or slight brown filters having a slight or a strong red-NIR absorption respectively. Their efficiency in energy saving is estimated by the determination of figures of merit and color coordinates. That highlights that $\left[\mathrm{Ta}_{6} \mathrm{Br}_{12}{ }_{12}\right]^{\mathrm{nt}}$-based composites are promising absorbers for energy saving applications.
\end{abstract}

\section{Introduction}

The International Energy Agency projects that world energy consumption will grow by 56 percent between 2010 and 2040. ${ }^{1}$ At the same time global warming emissions resulting from energy production will become a serious environmental problem due to greenhouse emission. Moreover, energy saving is needed to extend the remaining energy supplies and to leave enough time to find alternatives sources to fully replace fossil fuels. One of the largest potential for energy savings areas, in the short term may be found in the building, automobile or agriculture sectors due to their use of air conditioning and/or heating systems to regulate the indoor temperature. For instance, energy efficient smart glass or plastic transparent materialscould be able to reduce the energy consumption for houses, cars and greenhouses, owingto better thermal insulation by controlling near-infrared

a. Université de Rennes 1, UMR Institut des Sciences Chimiques de Rennes UR1-CNRS 6226, Equipe Chimie du Solide et Matériaux, 263 av. du Général Leclerc, 35042 Rennes, France.

${ }^{b .}$ CNRS-SaintGobain-NIMS, UMI 3629, Laboratory for Innovative Key Materials and Structures (LINK), National Institute of Material Science, 1-1 Namiki, Tsukuba 3050044, Japan.

c. Fine Particles Engineering Group, RCFM, National Institute of Material Science, 12-1 Sengen, Tsukuba, Japan.

d. NIMS-Saint-Gobain Center of Excellence for Advanced Materials, National

Institute of Material Science, 1-1 Namiki, Tsukuba, Ibaraki 305-0044, Japan.

e. RCFM, National Institute for Materials Science, 1-1 Namiki, Tsukuba, Ibaraki 3050044, Japan.

† Footnotes relating to the title and/or authors should appear here.

Electronic Supplementary Information (ESI) available: [details of any supplementary information available should be included here]. See DOI: $10.1039 / \times 0 \times x 00000 x$
(NIR) solar radiation. Indeed, NIR reflective or absorptive coating materials that are transparent in the visible andonly block transmission of NIR light from solar radiation or heat transfer are of great interest. ${ }^{2-10}$ The solar energy spectrum is distributed from thenear ultra-violet UV $(300-380 \mathrm{~nm})$ to visible $(380-780 \mathrm{~nm})$ and near infrared radiationNIR (780$3000 \mathrm{~nm}$ ). Virtually all UV radiation is absorbedby the earth's atmosphere, so approximately $95 \%$ of the energy content of solar radiation reaching earth's surface comes from the visible and the NIR range, at $43 \%$ and $52 \%$ respectively. When light impacts the surface of a material, it can be absorbed, transmitted or reflected (including scattering). NIR reflective materials are mainly inorganic including transition metal, doped oxides such as transparent conductive oxides (TCO). They are known to reflect thermal radiation and thus the heat transfer is simply blocked. ${ }^{2,5-7}$ Conversely, absorption of NIR light is the main source of heat gain in a material. NIR absorptive materials could be used as energy-saving material in two ways, (i) convert the portion of sunlight to thermal energy or electric power and (ii) block the NIR heat through absorbing and re-emitting the heat to outdoor atmosphere. A few metal oxides can absorb NIR light (with tungsten oxide most commonly employed for energy saving smart windows) but most of the NIR absorptive materials are organic with $\pi$ conjugation systems like polymethines or metal complexes like dithiolene with generally low durability. ${ }^{2,5-8}$ Usually, the preparation of smart window based on inorganic compounds involves expensive high vacuum deposition processes. ${ }^{2,7}$ We assume that solution-based routes should lead to easier and more versatile processes while maintaining lower cost. Moreover, enhanced control of near NIR radiation may be 
obtained by the realization of multifunctional systems. These systems may be achieved by the combination of several materials with a well-defined architecture following the nanoarchitectonics concept. ${ }^{11,12}$ Indeed, nano-architectured composites represent a new class of materials that integrate various dissimilar nanoscale building blocks including nanosized cluster units, nanoparticles, nanowires and nanofilms. A huge number of efforts have been made to develop strategies to assemble complex functional nanostructures in a hierarchical fashion for advanced devices and systems toward energy, environmental and sensing sectors. ${ }^{13}$ The heterogeneous composite nanostructured materials are composed by definition of multiple-nanocomponents, each tailored to address different application requirements. As one of the nanocomponents, nanometer sized metal clusters ( $<2 \mathrm{~nm}$ ) also called "nanoclusters", which consist of less than a few dozens of metal atoms such as $\mathrm{Au}$, $\mathrm{Ag}, \mathrm{Pd}, \mathrm{Pt}, \mathrm{Cu}, \mathrm{Mo}, \mathrm{Ta}, \mathrm{Re}$, could be defined as a link between atom and nanoparticle. ${ }^{14-19}$ Nanoclusters have attracted attention due to their unique electronic structures and the subsequent unusual physical and chemical properties. ${ }^{14-19}$ These species, which can be discrete or condensed by either ligands or metals, constitute the basic building blocks of a wide range of solid state, hybrid organic-inorganic and nanomaterials that can be prepared by solid state or solution chemistry and by their combination. ${ }^{20-25}$ The term "metal atom cluster" was introduced by F.A. Cotton in $1964^{26}$ to define a finite group of metal atoms (two or more) that are held together by metal-metal bonds, in addition to being bonded to other non-metal ligands. Octahedral metal atom clusters are commonly found with $4 \mathrm{~d}$ and $5 \mathrm{~d}$ element in inorganic solid state compounds prepared by solid state synthesis at high temperatures. They form face-capped $\left[\mathrm{M}_{6} \mathrm{~L}_{8}^{{ }^{i}} \mathrm{~L}_{6}^{\mathrm{a}}{ }_{6}\right]^{\mathrm{n}-}$ units or edge-bridged $\left[\mathrm{M}_{6} \mathrm{~L}_{12}^{\mathrm{i}} \mathrm{L}_{6}^{\mathrm{a}}\right]^{\mathrm{n}-}$ units with halides or mixtures of halogens and chalcogens. Owing to their unique intrinsic properties such as deep red luminescence, photocatalytic and catalytic properties, strong absorption in the visible, facecapped $\left[\mathrm{M}_{6} \mathrm{~L}_{8}^{\mathrm{i}} \mathrm{L}_{6}^{\mathrm{a}}\right]^{\mathrm{n}-\mathrm{s}}$ units can be integrated into several types of devices and nanocomposites affording a wide set of potential applications in biotechnologies, lighting, displays and photovoltaic cells. ${ }^{14,20,25,27}$ Hitherto, the possibility of using edge-bridged $\left[\mathrm{M}_{6} \mathrm{~L}_{12}^{\mathrm{i}} \mathrm{L}_{6}^{\mathrm{a}}\right]^{\mathrm{n}-}$ units in applicative nanomaterials or devices has received less attention than face-capped units. However, they are known to exhibit interesting physicochemical behaviours. For instance, $\left[\mathrm{Ta}_{6} \mathrm{Br}_{12}^{\mathrm{i}}\left(\mathrm{H}_{2} \mathrm{O}\right)_{6}^{\mathrm{a}}{ }_{6}^{\mathrm{nt}}\right.$ unit is commonly used in protein crystallography for phasing $\mathrm{X}$-ray crystal structures of macromolecules. ${ }^{28}$ Indeed, soaking biological crystals in a solution of $\left[\mathrm{Ta}_{6} \mathrm{Br}_{12}^{\mathrm{i}}\left(\mathrm{H}_{2} \mathrm{O}\right)_{6}^{\mathrm{a}}\right]^{\mathrm{n}+}$ unit leads to their green coloration after several days of incubation. Owing to their electron-richness, cluster units induce significant changes in crystal diffraction required for convenient phase calculation. It has been also demonstrated that $\left(M_{6} L_{12}^{i}\right)^{n+}$ edge-bridged metal cluster cores can be intercalated by an ion-exchange mechanism in smectite clay and oxidized in situ to metal oxide aggregates that function as molecular size pillars. ${ }^{29}$ Various types of reactions are catalyzed by edge-bridged clusters as demonstrated by
Chihara's group. ${ }^{30}$ In the solid state and when prepared at high temperatures in anhydrous conditions, various compositions and structure types can be obtained. They depend either on the neutrality or on the number of negative charges carried by the cluster units and in the latter case on the nature and disposition of counter cations around the clusters. ${ }^{31-34}$ Remarkably, all these solid state compounds are soluble in common solvent (water, alcohols, ketones, etc) affording interesting colored metal complexes with redox activities. The green color of $\left(\mathrm{M}_{6} \mathrm{~L}^{\mathrm{i}}{ }_{12}\right)$ cluster cores in solution and in particular the deep green-emerald color of $\left(\mathrm{Ta}_{6} \mathrm{Br}_{12}^{i}\right)$ cluster core is known for more than one century as described by Chabrié and Chapin. ${ }^{35}$ More than 50 years later, McCarley did an exhaustive investigation of physico-structural properties of $\mathrm{M}_{6} \mathrm{~L}_{12}^{\mathrm{i}} \mathrm{L}^{\mathrm{a}}{ }_{6}$. He showed that solutions of $\mathrm{M}_{6} \mathrm{~L}_{12}^{\mathrm{i}}$ cluster cores exhibit ultraviolet, visible, and near infrared absorption properties. ${ }^{36}$ In solution, these units can be reversibly oxidized leading to drastic modulation of optical properties giving brownish solutions. ${ }^{37,38}$ For $\left(\mathrm{Ta}_{6} \mathrm{Br}_{12}^{\mathrm{i}}\right)$ cluster cores, the oxidation of $\left[\mathrm{Ta}_{6} \mathrm{Br}_{12}^{i}\right]^{2+}$ in $\left[\mathrm{Ta}_{6} \mathrm{Br}_{12}^{i}\right]^{3+}$ and $\left[\mathrm{Ta}_{6} \mathrm{Br}_{12}^{\mathrm{i}}\right]^{4+}$ induces a red shift in the absorption bands of the UV-visible-NIR and a decrease in their intensity in the visible. ${ }^{39}$ Leveraging the concept of nanoarchitectonics, we have investigated edgebridged $\mathrm{M}_{6} \mathrm{~L}_{12}^{\mathrm{i}} \mathrm{L}_{6}^{\mathrm{a}}{ }_{6}$ cluster units for the design of multifunctional nanocomposite materials and devices. This, with the aim of combining UV-NIR absorptive and reflective properties with high transparency in visible, a switchable green/brown color and block transmission of NIR light, for energy saving applications. More precisely, this present work focuses on the realization of heat barriers for smart windows associating a TCO as NIR reflector and an initial green-emerald $\left(\mathrm{Ta}_{6} \mathrm{Br}_{12}^{\mathrm{i}}\right)$ cluster cores as pigment and UV-NIR absorber. Two approaches were explored. The first one consists in the control of cluster-based composite color for glass coating by controlling the oxidation state of the $\mathrm{Ta}_{6}$ cluster. The aim was to demonstrate the ability to stabilize green reduced or brown full oxidized $\mathrm{Ta}_{6}$ cluster in nanocomposite hybrid thin films. The second approach resides in tuning dynamically and reversibly $\mathrm{Ta}_{6}$ cluster absorption properties by an external stimuli like an applied voltage. Indeed, electrochromic cells for smart window is a topic of growing interest. ${ }^{6,8,40-42}$ They generally consist of electrochromic oxides where the color modification is induced by insertion/extraction of ions like protons or lithium cations. ${ }^{8,41-44}$ Here we explore the possibility to tune cluster solution color by the control of the oxidation states of $\left[\mathrm{Ta}_{6} \mathrm{Br}_{12}^{\mathrm{i}}\right]^{\mathrm{n}+}$ in designing the first $\mathrm{Ta}_{6}$-based electrochromic cell.

\section{Experimental Section}

$\mathrm{K}_{4} \mathrm{Ta}_{6} \mathrm{Br}_{18}$ compound was obtained by the reduction of tantalum pentabromide $\left(\mathrm{TaBr}_{5}\right)$ powder by tantalum powder in an alkaline medium $(\mathrm{KBr})$ at high temperature under inert atmosphere. Thus, $2.97 \mathrm{mmol}$ of $\mathrm{TaBr}_{5}$ (Alfa aesar, 99.9\% (metals basis)), $4.25 \mathrm{mmol}$ of Ta (Alfa aesar -325 mesh, Puratronic $^{\circledR}, 99.97 \%$ (metals basis))and $4.25 \mathrm{mmol}$ of $\mathrm{KBr}$ (Acros Organics, > 99\%, ACS reagent) were mixed together in a 
glovebox (AR atmosphere) and put into silicatube sealed under vacuum. The $\mathrm{K}_{4} \mathrm{Ta}_{6} \mathrm{Br}_{18}$ phase was obtained after annealing at $600^{\circ} \mathrm{C}$ during 24 hours in a rocking furnace.X-ray powder analysis of the powder revealed the presence of $\mathrm{K}_{4} \mathrm{Ta}_{6} \mathrm{Br}_{18}$ along with an excess of tantalum powder and $\mathrm{KBr}$. The latter were then removed bydissolution of synthesized powder (1.5 g) in absolute ethanol $(55 \mathrm{~mL})$ and filtration of the solution. GreenTa ${ }_{6} @ P V P$ colloidal solutions were prepared from up to $200 \mathrm{mg}$ of purified $\mathrm{K}_{4} \mathrm{Ta}_{6} \mathrm{Br}_{18}$ powder suspended in $10 \mathrm{ml}$ of ethanol. After hours of stirring various PVP (Aldrich, $M_{w}=$ $40000 \mathrm{~g} \mathrm{~mol}^{-1}$ ) amounts (from $1 \mathrm{~g}$ to $4 \mathrm{~g}$ )were added and the mixture was left under magnetic stirring overnight until to obtain a perfectly clear solution. Brown colloidal solution was prepared from green Ta ${ }_{6} @$ PVP (4 g of PVP) by adding some drops of liquid bromide until to switch the color solution from green to brown.

Ta $a_{6}$-based films (Ta $a_{6} @ P V P @ g l a s s$ and Ta $\left.a_{6} @ P V P @ I T O ~ f i l m s\right)$ were obtained by dip-coating of the green and brown $\mathrm{Ta}_{6} @ P V P$ colloidal solutions on soda lime glass and ITO@glass.Ta $a_{6} @ P V P$ solutions were placed in Teflon $^{\circledR}$ containers and the clean substrates were introduced in the solutions for two minutes of immersion. Then, the substrates were pulled up at various rates (from 20 to $200 \mathrm{~mm} / \mathrm{min}$ ). Finally, the films were dried at room temperature and ambient atmosphere.

The electrochromic cell consists on a two electrodes electrochemical circuit: a transparent $\mathrm{Sn}_{1-\mathrm{x}} \mathrm{In}_{\mathrm{x}} \mathrm{O}_{2}$ (ITO) glass (Techinstro, 8-10 $\Omega / \mathrm{sq}$ ) electrode and a transparent counterelectrode in platinum prepared by chemical deposition of platinum from hexachloroplatinic acid in distilled isopropanol ( $2 \mathrm{mgper} \mathrm{mL}$ ) on ITO glass substrate. The two electrodes were assembled together with a polymer spacer (Surlyn, $60 \mu \mathrm{m}$ ) to form the electrolyte space. A drop of the cluster-based electrolyte prepared from $100 \mathrm{mg}$ of $\mathrm{K}_{4} \mathrm{Ta}_{6} \mathrm{Br}_{18}$ dissolved in 4 $\mathrm{mL}$ of water was introduced through a free polymer spacer interspace and isolated with Araldite glue.

FE-SEM images were performed with a JEOL JSM 6301F microscope operating at $7 \mathrm{kV}$. STEM images were performed using a Hitachi SU8000 microscope operating at $30 \mathrm{kV}$. UV-VisNIR spectra were recorded using a Cary 5000. The difference of potential between the two electrodes of the electrochromic cell was applied using a PGSTAT 204 potentiostat.

X-ray photoelectron spectroscopy (XPS) analysis was performed on $\mathrm{K}_{4} \mathrm{Ta}_{6} \mathrm{Br}_{18}$ powder deposited on a carbon tape with a SigmaProbe (Thermo Fisher Scientific) spectrometer, equipped with the excitation source of monochromated Al-Ka line $(1486 \mathrm{eV})$. The pass energy was set at $20.0 \mathrm{eV}$ for measuring core-level spectra and at $100.0 \mathrm{eV}$ for measuring wide scan. The energy resolution of core-level spectra is around $0.2 \mathrm{eV}$. When electrical charging of the sample surface obviously occurred under X-ray irradiation, a charge neutralizer equipped with both $\mathrm{Ar}^{+}$ion and electron emitters was employed to remove the surface charge. Data treatments were carried out using the software Termo Avantage (Termo Fisher Scientific). In the spectral analyses, the spectral background was subtracted using Shirley's method ${ }^{45}$ and the observed spectra were fitted with mixed Gaussian-Lorentzian functions using the least-squares method to calculate relative peak positions and integrated peak intensites. The spectraenergy was calibrated with the first deconvolved $C$ 1s peak (attributed to the $\mathrm{C}-\mathrm{C}$ bonding) rescale at $285 \mathrm{eV}$.

XRD patterns were recorded by grazing incidence X-ray diffraction (GIXRD), to limit the substrate contribution, using a Rigaku SmartLab apparatus (Rigaku, Tokyo, Japan) equipped with a D/TeX Ultra 250 detector and $\mathrm{Cu}$ radiation in the $\theta-\theta$ configuration.Data were collected in the $10-90^{\circ} 2 \theta$ rangewith a step of $0.02^{\circ}$ and a speed of $1^{\circ} \mathrm{min}^{-1}$.

Scanning transmission electron microscopy (STEM) images were taken using a Cs-corrected JEOL JEM2100F microscope operating at $200 \mathrm{kV}$. It is equipped with a field-emission electron gun and incorporates multiple additional functions such as an energy-dispersive spectrometry (EDS) and a high sensitivity Z-contrast high angular annular dark field scanning transmission electron microscopy (HAADF-STEM) analysis. A sample was prepared by direct deposition of powder (scratch from thin film) on carbon-activated copper grids.

Raman scattering spectra of $\mathrm{K}_{4} \mathrm{Ta}_{6} \mathrm{Br}_{18}$ powder and $\mathrm{K}_{4} \mathrm{Ta}_{6} \mathrm{Br}_{18} @ \mathrm{PVP}$ deposited on glass substrate were measured using a LabRam High Resolution spectrometer coupled with a confocal microscope (Horiba Yobin Yvon), $600 \mathrm{~g} / \mathrm{mm}$ grating and $10 \times$ objective. A He-Ne $633 \mathrm{~nm}$ laser was used for scattering excitation. Raman spectra were recorded at room temperature with $100 \mathrm{~s}$ exposition and 2 accumulations. In order to probe the homogeneity of the sample coated on glass, point by point spectra on $5 \times 5 \mu \mathrm{m}^{2}$ areas were recorded using a step of $1 \mu \mathrm{m}$. Each point spectra was recorded with $1 \mathrm{~s}$ exposition and 2 accumulations. Spectra were average for each of the four measured area.

\section{Results and discussion}

\section{$\mathrm{Ta}_{6}$ cluster-based composite hybrid thin films}

The first approach of this study was focused on the realization of high transparent cluster-based UV-NIR composite filters for glass coating using $\mathrm{Ta}_{6}$ clusters as both a pigment and an UVNIR absorber. More precisely, we explored the incorporation of nanosized cluster-based $\mathrm{K}_{4}\left[\mathrm{Ta}_{6} \mathrm{Br}_{12}^{\mathrm{i}} \mathrm{Br}_{6}^{\mathrm{a}}\right]$ compounds into a polyvinylpyrrolidone (PVP)-based polymer matrix in order to form Ta $\mathrm{a}_{6} @ P V P$ composite for the coating on $\mathrm{Sn}_{1-\mathrm{x}} \mathrm{In}_{\mathrm{x}} \mathrm{O}_{2}$ (ITO), a NIR reflective glass substrate. This inorganic compound, known to exhibit an intense green coloration in solution, is based on $\mathrm{Ta}_{6}$ cluster covalently bonded to edge-bridged $\mathrm{Br}$ ligands $\left(\mathrm{L}^{\mathrm{i}}\right.$, where i stands for inner) to form $\left(\mathrm{Ta}_{6} \mathrm{Br}_{12}^{\mathrm{i}}\right)^{2+}$ cluster core which is stabilized by terminal $\mathrm{Br}$ ligands $\left(\mathrm{L}^{\mathrm{a}}\right.$, where a stands for apical), yielding a so-called $\left[\left(\mathrm{Ta}_{6} \mathrm{Br}_{12}^{\mathrm{i}}\right) \mathrm{Br}_{6}{ }_{6}\right]^{4-}$ cluster unit (Figure 1a). $\mathrm{K}_{4}\left[\mathrm{Ta}_{6} \mathrm{Br}_{12}^{\mathrm{i}} \mathrm{Br}_{6}^{\mathrm{a}}\right]$ was synthesized by solid state chemistry by reduction of $\mathrm{TaBr}_{5}$ precursor by metallic tantalum in an alkaline medium $(\mathrm{KBr})$ at high temperature according to a slightly modified published procedure. ${ }^{46}$ After cooling, excess of tantalum and $\mathrm{KBr}$ were removed bydissolution of the resulting product $(1.5 \mathrm{~g})$ in absolute ethanol $(55 \mathrm{~mL})$ and filtration of the solution.XRD diagram andXPS measurements performed on $\mathrm{K}_{4}\left[\mathrm{Ta}_{6} \mathrm{Br}_{12}^{\mathrm{i}} \mathrm{Br}_{6}^{\mathrm{a}}\right]$ powder clearly confirm the 
presence of octahedral [ $\mathrm{TaBr}_{12}^{\mathrm{i}} \mathrm{Br}_{6}^{\mathrm{a}}{ }_{6}$ ] clusters-based compound (Figures S1 and S2 and Table S1). The clusters were then dissolved in ethanol and a viscous Ta $_{6} @ P V P$ colloidal solution was formed by addition of PVP. This solution was then dipcoated on ITO@glass substrate (experimental section).

The presence of $\mathrm{Ta}_{6}$-based clusters in PVP films and theirgood dispersion were investigated by $\mathrm{X}$-ray diffraction (XRD), Scanning transmission electron microscopy (STEM) and Raman spectroscopy (Supporting Information). Using HAADF-STEM mode image in high resolution (Figure S3 and $\mathrm{S4}$ ), the relatively well dispersed $\mathrm{Ta}_{6}$ clusters inside the PVP matrix is clearly observed. The presence in PVP-based films of $\left[\mathrm{Ta}_{6} \mathrm{Br}_{12}^{\mathrm{i}} \mathrm{Br}_{6}^{\mathrm{a}}{ }_{6}\right]$ cluster units surrounded by potassium cations and the homogeneous composition revealing a very good dispersion of the clusters within the matrix were confirmed by Raman (Figure S5, S6 and S7) and XRD experiments (Figure S8). The optimization of the thickness and optical properties of the films were investigated. In this framework, various parameters such the Ta 6 @PVP solution viscosity and the dipping rate during the coating were optimized. The solution viscosity was modified by addition of various amount of PVP from $1 \mathrm{~g}$ to $4 \mathrm{~g}$ into cluster-based ethanolic solution $(7.5 \mathrm{mM})$. Specifically, each colloidal solution of clusters $\mathrm{Ta}_{6} @ P V P$ were prepared by dissolving $200 \mathrm{mg}$ of purified $\mathrm{K}_{4} \mathrm{Ta}_{6} \mathrm{Br}_{18}\left(\mathrm{M}_{\mathrm{w}}=2680 \mathrm{~g} \cdot \mathrm{mol}^{-1}\right)$ in $10 \mathrm{~mL}$ of ethanol and then by adding 1 to $4 \mathrm{~g}$ of PVP $\left(\mathrm{M}_{\mathrm{w}}=\right.$ $40000 \mathrm{~g} \mathrm{~mol}^{-1}$ ). Films denoted $\mathrm{Ta}_{6} @$ PVP@glass were obtained from these solutions after deposition by dip-coating on glass substrates at various dipping rates from 20 to $200 \mathrm{~mm} / \mathrm{min}$ (Figure $2 \mathrm{a}$ and $\mathrm{b}$ ).
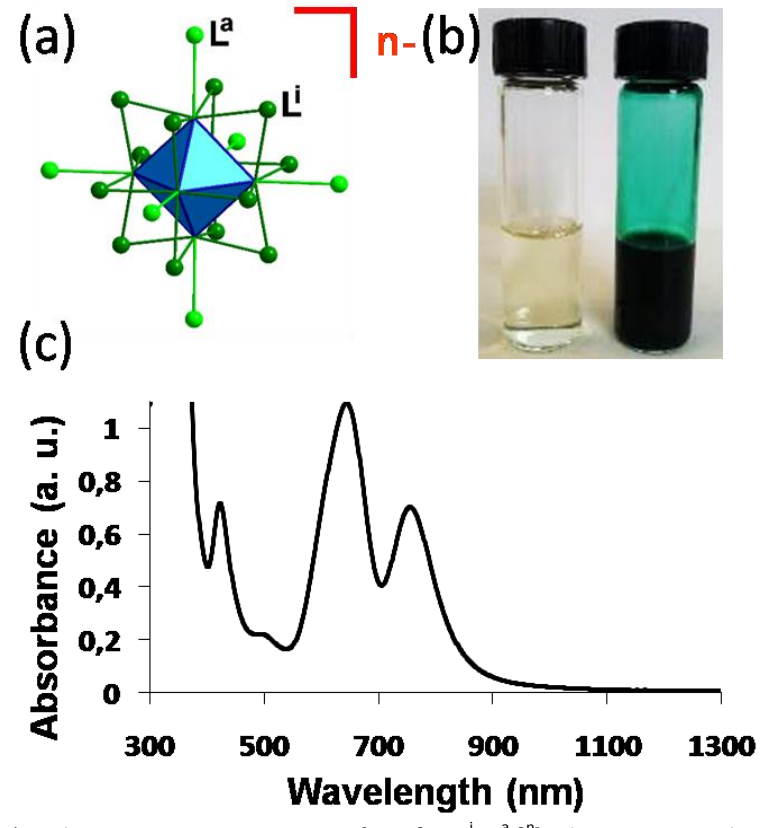

Fig.1(a) Schematic representation of a $\left[\mathrm{Ta}_{6} \mathrm{~L}_{12}^{\mathrm{i}} \mathrm{L}_{6}^{\mathrm{a}}\right]^{\mathrm{n}-}$ cluster unit. The $\mathrm{Ta}_{6}$ Octahedral cluster is represented in blue. Apical ligands are in terminal position (b) Camera image of theethanolic PVP solution without (left) and with $\mathrm{K}_{4} \mathrm{Ta}_{6} \mathrm{Br}_{18}$ (c) UV-vis-NIR spectrum of the diluted Ta $a_{6} @ P V P$ solution containing $4 \mathrm{~g}$ of PVP.

Soda lime glasses substrates were firstly used for the optimization of $\mathrm{Ta}_{6} @$ @PP solutions and coating conditions. Using this very simple chemical process, highly concentrated solutions with very good colloidal stability could be prepared for each PVP concentration. Ta 6 @PVP solutions show a dark emerald-green color (Figure $1 \mathrm{~b}$ ) corresponding to strong UVblue and red-NIR absorption bands. For example, the maxima of absorption peaks of the solution containing $4 \mathrm{~g}$ of PVP are located at 353, 423, 498, 644 and $756 \mathrm{~nm}$ (Figure 1c). As expected, the amount of added polymer drastically impacts the viscosity of solutions from $8 \mathrm{mPa}$.s for $1 \mathrm{~g}$ of PVP to 150 $\mathrm{mPa}$.s for $4 \mathrm{~g}$. It results in an increase of the thickness and so of the color intensity of films obtained after coating on glass substrates (Figure 2a). An increase of the thickness is observed by raising the dipping rate as well (Figure 2b). Finally, optimized Ta $\mathrm{T}_{6} @ P V P @ g l a s s$ films were obtained from a $\mathrm{Ta}_{6} @ P V P$ solution containing $4 \mathrm{~g}$ of PVP at a dipping rate of $160 \mathrm{~mm} / \mathrm{min}$. They have an average thickness of $13.7 \mu \mathrm{m}$ (see FE-SEM images on Figure 2d) and are homogeneous, smooth and highly transparent. They exhibit the same emerald-green color than that of the initial solution with the same absorption bands (maxima located at 366, 430, 511, 658 and $756 \mathrm{~nm}$ ) characteristic of the color of reduced $\left[\mathrm{Ta}_{6} \mathrm{Br}_{12}^{i}\right]^{2+}$ ions (Figure $2 \mathrm{c}$ and 1c). Ta 6 @PVP@ITO films were then fabricated by deposition of the same optimized $\mathrm{Ta}_{6} @ P V P$ solution (4 g of PVP in $10 \mathrm{~mL}$ of ethanol) on NIR reflective ITO@glass. Surprisingly, the thickness can reach $28 \mu \mathrm{m}$ for the same deposition conditions (concentration and rate, Figure 59). This may be due to a better affinity between the solution and the ITO surface. Indeed, it could be explained by higher electrostatic interactions between $\left[\mathrm{Ta}_{6} \mathrm{Br}^{\mathrm{i}}{ }_{12}\right]^{2+}$ cluster cores and ITO surface. Finally the UV-vis-NIR spectra sketched in Figure 3a highlight that the optical properties of $\mathrm{Ta}_{6} @ P V P @ I T O$ nanocomposite hybrid films correspond well to the combination of the NIR reflective properties (and UV absorption properties) of ITO substrate and the UV-vis-NIR absorption properties of the $\mathrm{Ta}_{6}$ clusters.

Thus from $\mathrm{K}_{4}\left[\mathrm{Ta}_{6} \mathrm{Br}_{12}^{\mathrm{i}} \mathrm{Br}_{6}^{\mathrm{a}}\right.$ ] cluster compound, we succeeded in producing a highly transparent dark green-emerald UV-NIR filter.

Next we investigated the ability to tune the visible and NIR absorption properties of the composite coatings by oxidation of $\left[\mathrm{Ta}_{6} \mathrm{Br}_{12}^{\mathrm{i}}\right]^{2+}$ cluster cores. As mentioned above, several published studies show that $\left[\mathrm{Ta}_{6} \mathrm{Br}_{12}^{\mathrm{i}}\right]^{2+}$ species can undergo two reversible one-electron oxidations and turn to $\left[\mathrm{Ta}_{6} \mathrm{Br}_{12}^{\mathrm{i}}\right]^{3+}$ or $\left[\mathrm{Ta}_{6} \mathrm{Br}_{12}^{\mathrm{i}}\right]^{4+}$ cluster core ions. It corresponds to a decrease of the valence electron concentration (VEC) per $\mathrm{Ta}_{6}$ cluster from 16 for $\left[\mathrm{Ta}_{6} \mathrm{Br}_{12}^{i}\right]^{2+}$ to $14\left[\mathrm{Ta}_{6} \mathrm{Br}_{12}^{\mathrm{i}}\right]^{4+} .{ }^{47}$ An emerald green solution is characteristic of the presence of $\left[\mathrm{Ta}_{6} \mathrm{Br}_{12}^{\mathrm{i}}\right]^{2+}$ species ( $V E C=16)$ whereas yellow, yellow-orange colors were mostly referenced for the $\left[\mathrm{Ta}_{6} \mathrm{Br}_{12}^{\mathrm{i}}\right]^{3+}(\mathrm{VEC}=15)$ and $\left[\mathrm{Ta}_{6} \mathrm{Br}_{12}^{\mathrm{i}}\right]^{4+}$ species (VEC $=14$ ) respectively. ${ }^{39}$ We explored the possibility to stabilize $\left[\mathrm{Ta}_{6} \mathrm{Br}_{12}^{\mathrm{i}}\right]^{3+/ 4+}$ oxidized species in the $\mathrm{Ta}_{6} @ P V P$ solution and in films after its deposition. Liquid bromide was used as it is known to easily oxidize $\left(M_{6} X_{12}\right)(M=N b$ or Ta and $\mathrm{X}=\mathrm{Cl}$ or $\mathrm{Br}$ ) clusters in alcoholic conditions ${ }^{48}$ and was added to the initial Ta 6 @PVP solution. A few drops of $\mathrm{Br}_{2}$ are sufficient to switch the solution color from green to brown. After deposition on glass substrates, the resulting highly transparent (oxidized-Ta $\mathrm{T}_{6}$ )@PVP@glass films exhibit the same brown color of the solution and are stable over time (Figure $3 b$ ). 
(a)
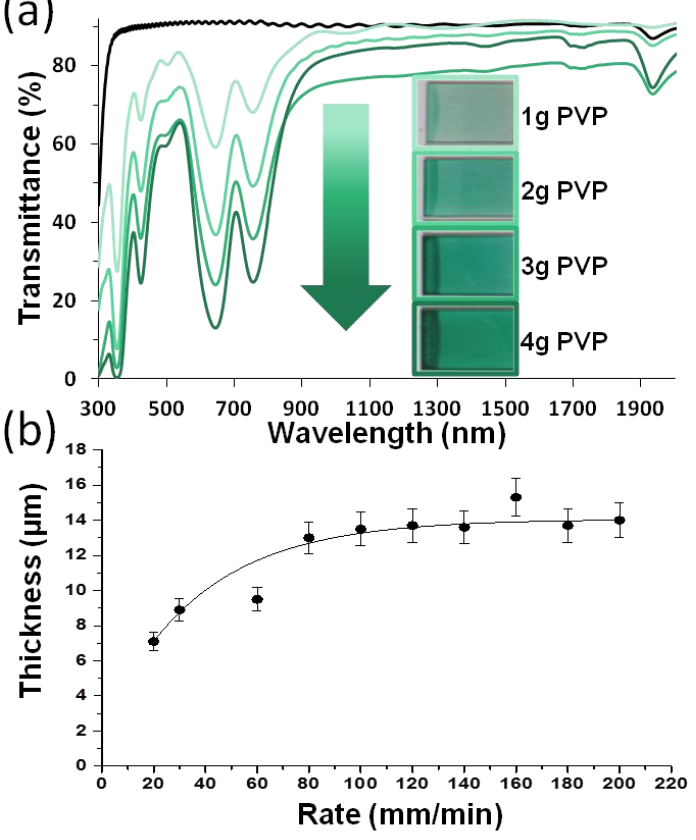

(c)

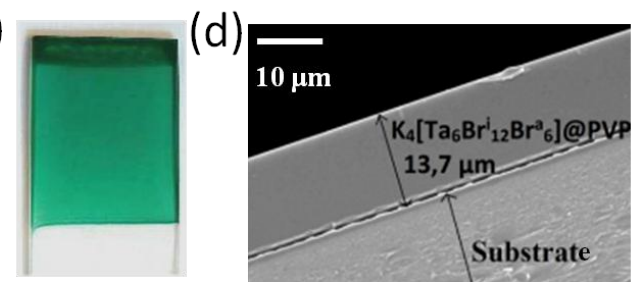

Fig. 2.(a)UV-vis-NIR spectra (without reference) and photographs of the Ta $a_{6} @ P V P @ g l a s s$ films prepared from Ta $a_{6} @ P V P$ solutions containg 1, 2, 3 or $4 \mathrm{~g}$ of PVP. (b) Thickness of Ta $@$ @VP@glass films prepared from Ta $@$ @ containing $4 \mathrm{~g}$ of PVP according the dipping rate. (c) Camera image of solution (4 g of PVP, $160 \mathrm{~mm} / \mathrm{min})$. (d) FE-SEM image of the cross section of $\mathrm{Ta}_{6} @ P V P @ g l a s s f i l m$.

This color variation corresponds to a gradual shift and decrease of the visible-NIR absorption bands compared with the initial green-emerald film spectrum (maxima of absorption peaks at 374, 450, 742 and $895 \mathrm{~nm}$, the peak around $500 \mathrm{~nm}$ is too small to be observed, Figure $3 \mathrm{~b}$ ). This is concomitant to an increase of a new NIR band around $895 \mathrm{~nm}$. It turns out that the oxidizedTa 6 @PVP@glass film spectrum, characterized by a strong peak at $900 \mathrm{~nm}$ and a shoulder around $750 \mathrm{~nm}$, looks like that of $\left[\mathrm{Ta}_{6} \mathrm{Br}_{12}^{\mathrm{i}}\right]^{3+}$-based solutions published by Speckelmeyer. ${ }^{39}$ This could be explained by the reverse disproportionation reaction $\left(\left[\mathrm{Ta}_{6} \mathrm{Br}_{12}^{\mathrm{i}}\right]^{2+}+\left[\mathrm{Ta}_{6} \mathrm{Br}_{12}^{\mathrm{i}}\right]^{4+} \rightarrow 2\right.$ $\left[\mathrm{Ta}_{6} \mathrm{Br}_{12}^{\mathrm{i}}\right]^{3+}$ ) which has a reaction constant relatively large according to Cooke et al., ${ }^{49}$ and seems to promote $\left[\mathrm{Ta}_{6} \mathrm{Br}_{12}\right]^{3+}$ species in solution. We succeeded in preparing green and brown NIR filters based on the functionalization of $\left[\mathrm{Ta}_{6} \mathrm{Br}_{12}^{\mathrm{i}}\right]^{\mathrm{nt}} @$ PVP on ITO and glass substrates. For all the films, we assume that the observed high transparency in the visible is a proof of the very good dispersion of the $1 \mathrm{~nm}$ metal cluster units inside the PVP matrix. This method clearly demonstrates the ability to prepare, highly transparent UV-NIR filters using a very simple, reproducible and low cost solution process that display tunable optical properties in the visible from green to brown and in the NIR with the appearance of a band around
$900 \mathrm{~nm}$ which absorbs the most energetic UV-NIR solar radiations.
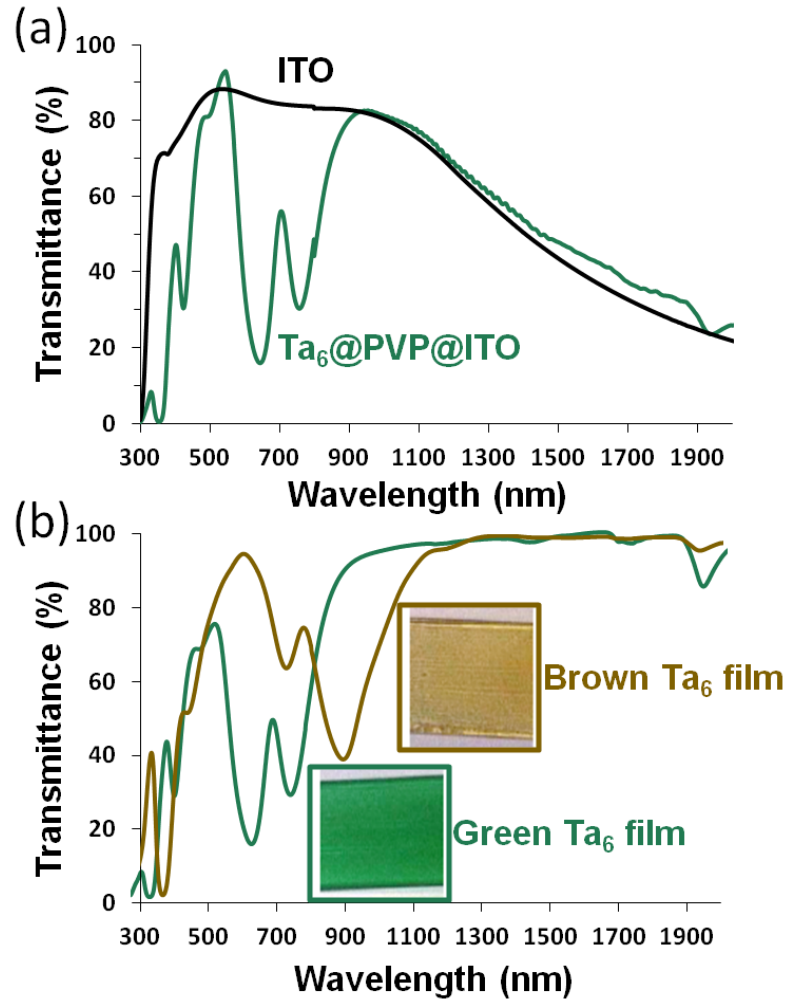

Fig.3.(a) UV-vis-NIR spectra (without reference) of ITO substrate and Ta 6 @PVP@ITO film obtained after dip-coating of the ethanoic Ta $a_{6} @ P V P$ solution on ITO substrate (4 g of PVP, $160 \mathrm{~mm} / \mathrm{min}$ ). (b) UV-Vis-NIR spectra (with the films.

\section{Design of $\mathrm{Ta}_{6}$ cluster-based electrochromic cell}

We established the possibility to tune irreversibly the optical properties of the $\mathrm{Ta}_{6}$-based films by adding $\mathrm{Br}_{2}$ into the initial solution. The second step was to investigate a dynamic control of these optical properties. Thus, we tried to drive the oxidation state of the cluster by imposing an external stimuli namely a potential difference to a cluster-based electrolyte solution. To achieve this goal, we prepared the first electrochromic cell based on $\mathrm{Ta}_{6}$ clusters (Figure 4). This cell consists in a two electrodes electrochemical circuit containing a transparent ITO@glass electrode and a transparent Pt@ITO@glass counter-electrode in platinum prepared by coating Pt-based solution on ITO@glass substrate (experimental section). These two electrodes were separated by the cluster-based electrolyte. Figure 5 shows UV-vis-NIR spectra and photographs of the cell under applied voltage. At 0 $\mathrm{V}$, the transmission spectrum of the electrochemical cell performs, as expected, with a combination between i) the characteristic absorption bands $(410,640$ and $750 \mathrm{~nm}$ ) of an emerald-green $\mathrm{Ta}_{6}$ clusters solution indicating the presence of $\left[\mathrm{Ta}_{6} \mathrm{Br}_{12}\right]^{2+}$ species $(352,410,640$ and $750 \mathrm{~nm})$ and ii) the spectrum of the two electrodes of the cell (i.e. ITO and Pt@ITO). On one hand, ITO layers exhibit a strong UV and NIR absorption due to ITO substrates (bandgap $>4 \mathrm{eV}$ ) and on the other hand, the Pt layer induces a slight decrease of transmittance in the visible. When a voltage is applied, the 
absorption bands in the visible decrease progressively and disappear around $2.5 \mathrm{~V}$. (a)

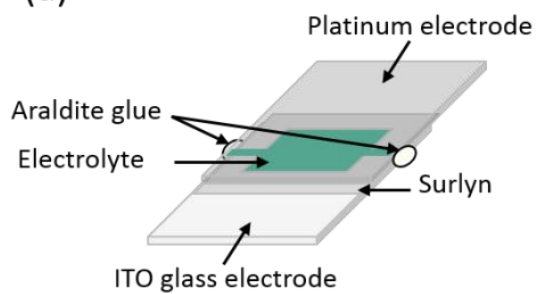

(b)

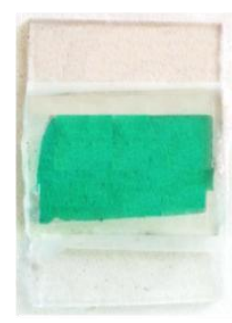

Fig. 4. (a) Scheme of the Ta6 electrochromic cell architecture and (b) photograph of the cell.

This induces a progressive discoloration of the initial green cell leading finally to a very light yellow-brown coloration.In term of time response, the discoloration appears almost instantaneous to the eye. In addition to this attenuation, red shifts of about $10-20 \mathrm{~nm}$ of the visible bands are observed and the absorption peak located at $880 \mathrm{~nm}$ in the NIR, characteristic of the oxidized species, appears and its intensity increases progressively with the voltage. These observations clearly indicate the oxidation of $\left[\mathrm{Ta}_{6} \mathrm{Br}_{12}^{\mathrm{i}}\right]^{2+}$ species. Indeed the absorption spectrum upon $3 \mathrm{~V}$ applied voltage looks like that of the brown (oxidized-Ta ${ }_{6}$ )@PVP@ITO. Two slight differences are observed: i) the second peak around $750 \mathrm{~nm}$ is reduced markedly for the electrochromic cell and ii) a relatively small shoulder emerges around $1000 \mathrm{~nm}$ near the strong NIR peak. These differences indicate that the shape of the electrochromic cell spectrum is closer to that of $\left[\mathrm{Ta}_{6} \mathrm{Br}_{12}^{\mathrm{i}}\right]^{4+}$ species in solution published by Spreckelmeyer et al. ${ }^{39}$ It is therefore reasonable to suppose that the reverse reproportionation reaction cannot occur in the electrochemical cell due to its and the high imposed potential.

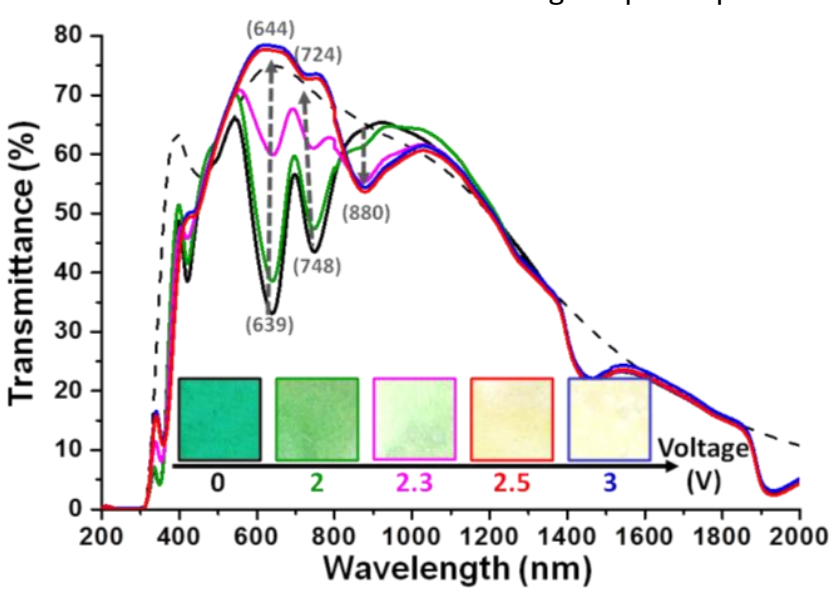

Fig. 5. UV-vis-NIR spectra and photographs of $\mathrm{Ta}_{6}$ electrochromic cell unde 政 the empty cell (without $\mathrm{Ta}_{6}$ aqueous solution).

Thus, we succeeded in switching between an emerald-green transparent cell to an almost brown transparent cell blocking $\mathrm{NIR}$ radiations from $800 \mathrm{~nm}$. Moreover, an important feature is that the variation of the intensity and the position of the absorption bands according to the applied voltage are fully reversible in the range of $0-3 \mathrm{~V}$. Indeed, after the application of a voltage, the cell quickly recovers (less than $5 \mathrm{~s}$ ) the initial emerald-green color just by disconnecting the electrodes of the electrical circuit. After $3 \mathrm{~V}$, the electrolyte solution turns to a dark brown-black color revealing the irreversible alteration of the $\mathrm{Ta}_{6}$ cluster. The aim of this study was to realize a proof of concept however in term of cyclability and durability we observed: i) no significant decrease of absorption peaks after several cycles (5 cycles) and ii) no alteration of transmittance spectra after a first test and two weeks of storage, respectively.

We succeeded in controlling dynamically the optical properties of $\mathrm{Ta}_{6}$ clusters in solution by tuning the oxidation state of $\left[\mathrm{Ta}_{6} \mathrm{Br}_{12}\right]^{\mathrm{n}+}$. We now propose redox processes are occurring within the electrochromic cell. Indeed, as already reported in the literature ${ }^{49,50}$ and confirmed during the study in similar conditions (supporting information), the divalent $\left[\mathrm{Ta}_{6} \mathrm{Br}_{12}^{\mathrm{i}}\right]^{2+}$ cluster core ion tends to be oxidized into the tri- $\left[\mathrm{Ta}_{6} \mathrm{Br}_{12}^{\mathrm{i}}\right]^{3+}$ and quadrivalent $\left[\mathrm{Ta}_{6} \mathrm{Br}_{12}^{\mathrm{i}}\right]^{4+}$ ions in aqueous solution at potentials of 0.35 and $0.65 \mathrm{~V} / \mathrm{SCE}$ respectively, leading a color modification under voltage. In order to have a correspondence between these values and the voltage applied to our two electrodes system, we investigated the redox process of this $\mathrm{Ta}_{6}$ cluster solution in the conditions of the electrochromic cell namely by using a working electrode in ITO@glass and a counter-electrode/reference (the counter-electrode and reference cables are connected together) in Pt@ITO@glass. As shown in Figure S10a the two oxidation peaks can be observed but the redox potentials or more precisely the redox voltages are slightly shifted compared to those determined using the three electrodes circuit $(0.26 \mathrm{~V}$ and $0.71 \mathrm{~V}$ versus 0.42 and $0.63 \mathrm{~V} / \mathrm{Ag} / \mathrm{AgCl}$ for each wave, respectively). However, the medium potential (around $0.42-0.46 \mathrm{~V}$ or $\mathrm{V} / \mathrm{Ag} / \mathrm{AgCl}$ ) defined here as $\mathrm{E}^{\circ}\left(\left[\mathrm{Ta}_{6} \mathrm{Br}_{12}^{\mathrm{i}}\right]^{2+} /\left[\mathrm{Ta}_{6} \mathrm{Br}_{12}^{\mathrm{i}}\right]^{4+}\right)=\left[\mathrm{E}^{\circ}\left(\left[\mathrm{Ta}_{6} \mathrm{Br}_{12}^{\mathrm{i}}\right]^{2+} /\left[\mathrm{Ta}_{6} \mathrm{Br}_{12}^{\mathrm{i}}\right]^{3+}\right)\right.$ $\left.+\mathrm{E}^{\circ}\left(\left[\mathrm{Ta}_{6} \mathrm{Br}_{12}^{i}\right]^{3+} /\left[\mathrm{Ta}_{6} \mathrm{Br}_{12}^{i}\right]^{4+}\right)\right] / 2$ is comparable in the two experimental conditions which suggests that the actual difference lies in the kinetics of the process. The redox processes occur in the electrochemical cell below $0.71 \mathrm{~V}$ (Figure S10a). However no optical change can be observed at an applied voltage ranging between 0 and $2 \mathrm{~V}$ which corresponds to the stability domain of the solvent (Figure $\mathrm{S} 10 \mathrm{~b})$. This suggests that no macroscopic $\mathrm{Ta}_{6}$ oxidation state modification occurs under this voltage. This may be explained by a limitation of mass transfer at the electrodes, a kinetic limitation or the establishment of a dynamic redox equilibrium which limits the amount of oxidized species in solution. This equilibrium would be created by the oxidation on the anode of $\left[\mathrm{Ta}_{6} \mathrm{Br}_{12}^{\mathrm{i}}\right]^{2+}$ species into $\left[\mathrm{Ta}_{6} \mathrm{Br}_{12}^{\mathrm{i}}\right]^{3+/ 4+}$ species and the reduction of these oxidized species into $\left[\mathrm{Ta}_{6} \mathrm{Br}^{\mathrm{i}}{ }_{12}\right]^{2+}$ on the cathode after migration through the electrolyte under voltage. However above $2 \mathrm{~V}$, outside of the water stability domain (Figure S10b), redox processes occur. They induce the stabilization of oxidized $\left[\mathrm{Ta}_{6} \mathrm{Br}_{12}^{\mathrm{i}}\right]^{3+/ 4+}$ species and lead to the cell color variation. These reactions seem to involve the solvent. This can occur according to two mechanisms: i) water is oxidized and reduced at the two electrodes and the oxygen produced could oxidize the $\left[\mathrm{Ta}_{6} \mathrm{Br}_{12}{ }^{i}\right]^{2+}$ species or ii) water is reduced at the cathode and the $\left[\mathrm{Ta}_{6} \mathrm{Br}_{12}^{i}\right]^{2+}$ species are oxidized at the anode. The first mechanism could be consistent with the applied 
voltage (Figure S10b shows that the solvent oxidation, $\mathrm{H}_{2} \mathrm{O} / \mathrm{O}_{2}$ redox couple, occurs around $1.5-2 \mathrm{~V}$ ) but if water is reduced at the counter electrode we can suppose the concomitant reduction of oxidized $\left[\mathrm{Ta}_{6} \mathrm{Br}_{12}^{\mathrm{i}}\right]^{\mathrm{n}+}$ species. In any case, the occurrence of bubbles during the color modification clearly indicates redox process including the solvent. It appears necessary to explore the integration of other transparent redox species to more easily control the oxidation of $\left[\mathrm{Ta}_{6} \mathrm{Br}_{12}\right]^{2+}$ under moderated voltage without solvent reaction.

\section{Characterization of the balance between daylight supply and solar thermal blocking: $\mathrm{Ta}_{6}$ cluster-based in composite hybrid film and electrochromic device}

The efficiency in energy saving of the new $\mathrm{Ta}_{6}$-based UV and NIR filters (i.e green $\mathrm{Ta}_{6}$-based composite film and electrochromic cell at various voltages) was estimated via the determination of the different figure of merit (FOM) values such $T_{\text {vis }}, T_{\text {sol }}, T_{\text {vis }} / T_{\text {sol }}$ and the color coordinates ( $x, y$ and $z$ ). $T_{\text {sol }}$ and $T_{\text {vis }}$ correspond to the solar and the visible transmittance, respectively. They are calculated using similar methods, namely by integration of the spectral transmittance of a window weighted either with the normalized solar energy distribution spectrum for $\mathrm{T}_{\text {sol }}$ or with the photopic response of the human eye for $\mathrm{T}_{\text {vis }}$ (more details are gathered in $\mathrm{SI}$ ). ${ }^{51}$ The FOM values and color coordinates are batched in the table 1 and depicted in the International Commission on Illumination (CIE 1931) color space chromaticity diagram (Figure 6).

Table 1. FOM values and color coordinates of green Ta ${ }_{6} @ P V P @ I T O$ film and electrochromic cell at various voltages. ITO and electrochromic cell without electrolyte are taken as references.

\begin{tabular}{llllllc}
\hline Name & $\mathbf{x}$ & $\mathbf{y}$ & $\mathbf{z}$ & $\mathbf{T}_{\text {vis }}$ & $\mathbf{T}_{\text {sol }}$ & $\mathbf{T}_{\text {vis }} / \mathbf{T}_{\text {sol }}$ \\
\hline ITO 8-12 $\Omega$ /sq & 0.318 & 0.340 & 0.342 & 87.6 & 78.0 & 1.12 \\
\hline $\begin{array}{l}\text { Green- } \\
\text { Ta6 @PVP@ITO }\end{array}$ & 0.268 & 0.387 & 0.345 & 69.9 & 55.3 & 1.26 \\
\hline Electrochromic cells & & & & & & \\
- Without & 0.337 & 0.346 & 0.317 & 67.9 & 58.8 & 1.16 \\
electrolyte & & & & & & \\
-With electrolyte: & & & & & & \\
At 0V & 0.296 & 0.359 & 0.345 & 56.8 & 48.1 & 1.18 \\
At 2V & 0.302 & 0.361 & 0.337 & 61.3 & 50.3 & 1.22 \\
At 2.3V & 0.328 & 0.362 & 0.310 & 66.8 & 53.4 & 1.25 \\
At 2.5V & 0.346 & 0.363 & 0.291 & 71.3 & 56.6 & 1.26 \\
At 3V & 0.346 & 0.362 & 0.292 & 72.0 & 57.3 & 1.26 \\
\hline
\end{tabular}

We can note the gain in solar control efficiency brought by $\mathrm{Ta}_{6}$ cluster-based layers in film coating and in electrochromic cell. Indeed, $T_{\text {vis }} / T_{\text {sol }}$ is higher for the green Ta $a_{6} @ P V P @ I T O$ film (1.26) and the electrochemical cell based on $\mathrm{Ta}_{6}$ electrolyte (until 1.26) than the ITO substrate (1.12) and the empty cell (1.16). Moreover, a slight cell efficiency gain is observed by oxidation of the $\mathrm{Ta}_{6}$ cluster (from a $\mathrm{T}_{\mathrm{vis}} / \mathrm{T}_{\text {sol }}$ of 1.18 for the green cell at $0 \mathrm{~V}$ to 1.26 for the brown one at $3 \mathrm{~V}$ ). By comparison, an ideal window, corresponding to a visible transparent film (90\% of transmittance between $400-780 \mathrm{~nm}$ ) absorbing $100 \%$ of UV (200-400 nm) and NIR (780-2000) radiations, has a $T_{\text {vis }} / T_{\text {sol }}$ ratio is 1.85 whereas most of composites reported in the literature have an experimental value close to 1 . Finally, both the green $\mathrm{Ta}_{6}$-based composite film and electrochromic cell evidence a calculated visible transmittance $\left(T_{\text {vis }}\right)$ higher than $50 \%$, which is the lower limit acceptable for window applications. ${ }^{52}$ All of this highlights that $\left[\mathrm{Ta}_{6} \mathrm{Br}_{12}^{\mathrm{i}}\right]^{\mathrm{n}+}$-based compositesare promising absorbers for energy saving applications.

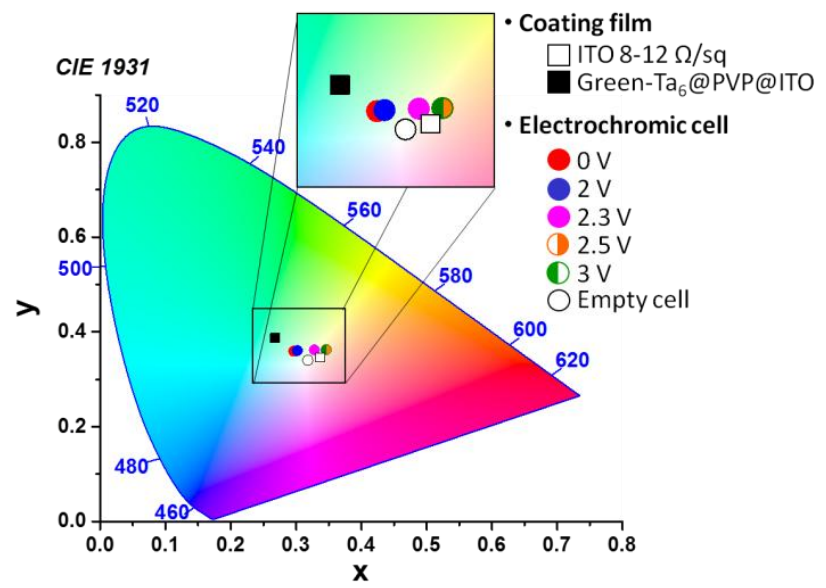

Fig. 6. CIE chromaticity coordinates of green Ta6@PVP@ITO film, electrochromic cell at various voltages and references:ITO substrate and empty electrochromic cell (i.e. electrochromic cell without $\mathrm{Ta}_{6}$-basedelectrolyte).

\section{Conclusion}

We successfully fabricated for the first time $\mathrm{Ta}_{6}$ cluster-based UV and NIR filters withhigh transparency in thevisible. Firstly, we prepared highly concentrated colloidal solutions of $\mathrm{Ta}_{6}$ clusters in presence of ethanol using PVP. We succeeded in stabilizing in the polymer matrix green reduced $\left[\mathrm{Ta}_{6} \mathrm{Br}_{12}\right]^{2+}$ species or brown oxidized $\left[\mathrm{Ta}_{6} \mathrm{Br}_{12}\right]^{3+}$ species by the addition of $\mathrm{Br}_{2}$ leading to the control of their solution color. These solutions were used to prepare,through a very simple, reproducible and low cost solution process, films exhibiting i) high transparency, ii) switchable strong color from emeraldgreen to brown and iii) modulated absorption in the red-NIR. We explored the ability to control dynamically the optical properties by the fabrication of the first $\mathrm{Ta}_{6}$-based electrochromic cell. This two electrodes cell allows a reversible switch from a green cell having a slight red-NIR absorption to a slight brown cell having a strong NIR absorption by altering the oxidation state of the cluster. It is the first proof of concept concerning the realization of electrochromic UV-NIR filters having tunable NIR absorption. This first device paves the way to the integration of metal clusters as building blocks for the design of multifunctional nanocomposite materials in energy saving applications such smart window.

\section{Acknowledgements}

This work was carried out as part of the France-Japan international framework (UMI 3629-LINK Center). It was 
supported by Saint-Gobain, CNRS, the University of Rennes 1, Région Bretagne (France), and NIMS (Japan). The authors thank University of Rennes 1 for the FE-SEM images as well as the people involved in LINK coordination, particularly Dr. Mari Kono, David Lechevalierand Dr. Benjamin Dierre of Saint-Gobain Japan.Raman investigations were performed using facilities available on SIR Plateform 'SIR for Spectroscopie et Imagerie Raman' from UMS 2001 CNRSUniversité Rennes 1 . Authors are very grateful to Bertrand Lefeuvre from ISCR UMR 6226 CNRS-Université Rennes 1 and Alain Moréac from IPR UMR 6252 CNRS-Université Rennes1.

\section{Notes and references}

¥Footnotes relating to the main text should appear here. These might include comments relevant to but not central to the matter under discussion, limited experimental and spectral data, and crystallographic data.

* Email: adele.renaud@hotmail.fr; stephane.cordier@univrennes1.fr; fabien.grasset@univ-rennes1.fr

grasset.fabien@nims.go.jp

1 International Energy Agency, World Enery Outlook, 2013.

2 G. B. Smith, C. A. Deller, P. D. Swift, A. Gentle, P. D. Garrett, W. K. Fisher, J. Nanopart. Res., 2002,4, 157.

3 S. Schelm, G.B. Smith, P.D. Garrett, W.K. Fisher, J. Appl. Phys., 2005,97, 124314

4 N. L. Stokes, J.A. Edgar, A.M. McDonagh, M.B. Cortie, J. Nanopart. Res., 2010, 12, 2821.

5 J. Fabian, Dyes and Pigments, 2010,84, 36.

6 A. Llordes, G. Garcia, J. Gazquez, D. J. Milliron, Nature, 2013, $500,323$.

7 I. Trenque, S. Mornet, E. Duguet, J. Majimel, A. Brûll, K. Teinz, E. Kemnitz, M. Gaudon, Opt. Mater.,2013, 35, 661.

8 C. G. Granqvist, Thin Solid Films, 2014, 564,1.

9 E. Lichtfouse, Sustainable Agriculture Reviews, Springer, 2015, 18.

10 F. Pacheco-Torgal, J. Labrincha, L. Cabeza, C. G. Granqvist, Eco-efficient Materials for Mitigating Building Cooling Needs: Design, Properties and Applications, Woodhead Publishing, 2015, 56.

11 K. Ariga, Y. Yamauchi, G. Rydzek, Q. Ji, Y. Yonamine, K. C.-W Wu, J.P. Hill., Chem. Lett., 2014,43, 36.

12 K. Ariga, A. Vinu, Y. Yamauchi, Q. Ji, J.P. Hill, Bull. Chem. Soc. Jpn.,2012,85, 1.

13 R. Liu, J. Duaya, S. B. Lee, Chem. Commun.,2011, 47, 1384.

14 S. Cordier, F. Grasset, Y. Molard, M. Amela-Cortes, R. Boukherroub, S. Ravaine, M. Mortier, N. Ohashi, N. Saito, H. Haneda, J. Inorg. Organomet. Polym., 2015, 25, 189.

15 Y. Lu, W. Chen, Chem. Soc. Rev., 2012, 41, 3594.

16 R.C. Jin, Nanoscale, 2010, 2, 343.

17 L. Shang, S. Dong, G.U. Nienhaus, Nano Today, 2011, 6, 401.

18 H.-T. Sun, Y. Sakka, Sci. Technol. Adv. Mater.,2014, 15, 014205.

19 S. Cordier, Y. Molard, K.A. Brylev, Y.V. Mironov, F. Grasset, B. Fabre, N.G. Naumov, J. Clust. Sci., 2015, 26, 53.

20 C. Neaime, M. Amela-Cortes, F. Grasset, Y. Molard, S. Cordier, B. Dierre, M. Mortier,T. Takei, K. Takahashi, H. Haneda, M. Verelst, S. Lechevallier, Phys.Chem.Chem.Phys. 2016, 18, 30166.

21 T. G. Troung, B. Dierre, F.Grasset, N. Saito, N. Saito, T. K. N. Nguyen, K. Takahashi, T. Uchikoshi, M. Amela-Cortes, Y. Molard, S. Cordier, N. Ohashi, Sci. Technol. Adv. Mater.,2016, 17, 443.
22 Y. Molard, F. Dorson, V. Circu, T. Roisnel, F. Artzner, S. Cordier, Angew. Chem. Int. Ed.,2010, 49, 3351.

23 Y. Molard, C. Labbe, J. Cardin, S. Cordier, Adv. Funct. Mater.,2013, 23, 4821.

24 T. Aubert, N. Nerambourg, N. Saito, H. Haneda, N. Ohashi, M. Mortier, S. Cordier, F. Grasset, Part. Part. Syst. Charact.,2013,30, 90.

25 M. Amela-Cortes, A. Garreau, S. Cordier, E. Faulques, J.-L. Duvail, Y. Molard, J. Mater. Chem. C, 2014, 2, 1545.

26 F.A. Cotton, Inorg. Chem.,1964, 3, 1217.

27 A. Renaud, F. Grasset, B.Dierre, T. Uchikoshi, N. Ohashi, T. Takei, A. Planchat, L. Cario, S. Jobic, F. Odobel, S. Cordier, ChemistrySelect,2016, 1, 2284.

28 J. Löwe, D Stock, B Jap, P Zwickl, W Baumeister, R Huber, Science, 1995, 268, 533

29 S. P. Christiano, J. Wang, T. J. Pinnavaia, Inorg. Chem.,1985, 24,1222.

30 S. Nagashima, S. Kamiguchi, T. Chihara, Metals, 2014, 4, 235.

31 D. Bauer, H.-G. von Schnering, Z. Anor. Allg. Chem.,1968, 361, 259.

32 S. Cordier, C. Perrin, M. Sergent, Z. Anor. Allg. Chem.,1993, 619, 621.

33 S. Cordier, C. Loisel, C. Perrin, M. Sergent, J. Solid State Chem., 1999, 147, 350.

34 S. Cordier, C. Perrin, M. Sergent,J. Solid State Chem.,1995, 118, 274.

35 a) P. C. Chabrie, Compt. rend.,1907, 144, 804; b) W. H. Chapin, J. Am. Chem, Soc.,1940, 32, 323.

36 R. E. McCarley, J. C. Boatman, Inorg, Chem., 1965,4, 1486.

37 R. E. McCarley, B. G. Hughes, F. A. Cotton, R. Zimmerman, Inorg. Chem.,1965,4, 1491.

38 J. H. Espenson, R. E. McCarley, J. Am. Chem. Soc.,1966, 88 1063.

39 B. Spreckelmeyer, H. Schäfer, J. Common Met.,1967, 13, 127.

40 T. E. Williams, C. M. Chang, E. L. Rosen, G. Garcia, E. L. Runnerstrom, B. L. Williams, B. Koo, R. Buonsanti, D. J. Milliron, B. A. Helms, J. Mater. Chem. C, 2014, 2, 3328.

41 D.T. Gillaspie, R.C. Tenent, A.C. Dillon, J. Mater. Chem.,2010, 20, 9585.

42 C.M. Lampert, Sol. Energy Mater.,1984, 11, 1.

43 C.G. Granqvist, Handbook of Inorganic Electrochromic Materials, Elsevier,Amsterdam, The Netherlands, 1995.

44 L. Berggren, A. Azens, G.A. Niklasson, J. Appl. Phys.,2001, 90, 1860.

45 D. A. Shirley, Phys. Rev. B1972, 5, 4709.

46 F. W. Koknat, J. A. Parson, A. Vongvusharintra, Inorg. Chem. 1974,13, 1699.

47 R. Eisenbraun, H. Schäfer, Z. Anorg. Allg. Chem., 1985,530, 222.

48 B. G. Hughes, J. L. Meyer, P. B. Fleming, R. E. McCarley, Inorg Chem.,1970,9, 1343.

49 N. E. Cooke, T. Kuwana, J. H. Espenson, Inorg. Chem.,1971,10, 1081.

50 H. Schäfer, B. Plautz, H. Plautz, Z. Anorg. Allg. Chem.,1972, 392, 10.

51 G. B. Smith, C. A. Deller, P. D. Swift, A. Gentle, P. D. Garrett, W. K. Fisher, J. Nanopart. Res., 2002, 4, 157.

52 a) G. B. Smith, C. A. Deller, P. D. Swift, A. Gentle, P. D. Garrett, W. K. Fisher, J. Nanopart. Res.,2002, 4, 157 ; b) S. Schelm, G.B. Smith, P.D. Garrett, W.K. Fisher, J. Appl. Phys.,2005, 97, 124314 ; c) N. L. Stokes, J.A. Edgar, A.M. McDonagh, M.B. Cortie, J. Nanopart. Res.,2010, 12, 2821 ; d) M. Carboni, M. Carravetta, X. L. Zhang, E. Stulz, J. Mater. Chem. C,2016, 4, 1584. 